\title{
Stromal-Derived Factor-1 (CXCL12) Regulates Laminar Position of Cajal-Retzius Cells in Normal and Dysplastic Brains
}

\author{
Mercedes F. Paredes, ${ }^{1,2}$ Guangnan Li, ${ }^{1,3}$ Omri Berger, ${ }^{3}$ Scott C. Baraban, ${ }^{1,2}$ and Samuel J. Pleasure ${ }^{1,3}$ \\ ${ }^{1}$ Neuroscience Program and Departments of ${ }^{2}$ Neurosurgery and ${ }^{3}$ Neurology, University of California, San Francisco, California 94143
}

\begin{abstract}
Normal brain development requires a series of highly complex and interrelated steps. This process presents many opportunities for errors to occur, which could result in developmental defects in the brain, clinically referred to as malformations of cortical development. The marginal zone and Cajal-Retzius cells are key players in cortical development and are established early, yet there is little understanding of the factors resulting in the disruption of the marginal zone in many types of cortical malformation syndromes. We showed previously that treatment with methylazoxymethanol in rats causes marginal zone dysplasia with displacement of Cajal-Retzius cells to deeper cortical layers. Here we establish that loss of activity of the chemokine stromal-derived factor-1 (SDF1) (CXCL12), which is expressed by the leptomeninges, is necessary and sufficient to cause marginal zone disorganization in this widely used teratogenic animal model. We also found that mice with mutations in the main receptor for SDF1 (CXCR4) have Cajal-Retzius cells displaced to deeper cortical layers. Furthermore, by inhibiting SDF1 signaling in utero by intraventricular injection of a receptor antagonist, we establish that SDF1 signaling is required for the maintenance of Cajal-Retzius cell position in the marginal zone during normal cortical development. Our data imply that cortical layering is not a static process, but rather requires input from locally produced molecular cues for maintenance, and that complex syndromes of cortical malformation as a result of environmental insults may still be amenable to explanation by interruption of specific molecular signaling pathways.
\end{abstract}

Key words: lamination; cortex; cortical dysplasia; migration; marginal zone; teratogen

\section{Introduction}

The six-layered mammalian neocortex is formed by neurons, generated in the proliferative zone lining the ventricles migrating radially to form the cortical plate in a characteristic inside-out gradient based on birthdate. The earliest of these cells split the previously formed preplate into a superficially placed marginal zone, containing neurons of cortical layer I, and the subplate, the boundary with the future white matter. Cajal-Retzius cells are a unique cell type populating the marginal zone, directly adjacent to the meninges. Cajal-Retzius cells regulate cortical lamination by secreting the glycoprotein reelin (Ogawa et al., 1995) as well as producing other factors that help support radial glial fibers, the primary conduits for neuronal migration (Anton et al., 1997; Super et al., 1997). Very recent studies suggest that Cajal-Retzius cells are generated in up to three discrete germinative zones and migrate long distances tangentially to establish themselves in the marginal zone during early gestation (Takiguchi-Hayashi et al.,

\footnotetext{
Received June 19, 2006; revised Aug. 2, 2006; accepted Aug. 2, 2006.

This work was supported by a Predoctoral Research Training Fellowship from the Epilepsy Foundation of America (M.F.P.), National Institute of Mental Health Grant K02 MH074958 (S.J.P.), funds from the National Alliance for Autism Research (S.J.P.), and National Institute of Neurological Disorders and Stroke Grant R01 NS40272 (S.C.B.). We thank Drs. John Rubenstein, Louis Ptacek, Lily Jan, and Louis Rechardt for helpful discussions and comments on this manuscript. We also thank Dr. Oscar Marin for helpful comments.

Correspondence should be addressed to Samuel J. Pleasure at the above address. E-mail: sam.pleasure@ ucsf.edu.

DOI:10.1523/JNEUROSCI.2575-06.2006

Copyright $\odot 2006$ Society for Neuroscience $\quad$ 0270-6474/06/269404-09\$15.00/0
}

2004; Bielle et al., 2005; Muzio and Mallamaci, 2005). Loss of Cajal-Retzius cells (or reelin expression) results in loss of the inside-out pattern of radial migration required to generate the normal laminar organization of the neocortex (Ogawa et al., 1995; Super et al., 2000). However, recent studies showed that genetic ablation of the fraction of Cajal-Retzius cells derived from the cortical hem or lateral sources had somewhat less than expected effects on neocortical lamination (Bielle et al., 2005; Yoshida et al., 2006). In humans, reelin mutations lead to a similar widespread cortical neuronal migration phenotype with associated cerebellar hypoplasia (Kato and Dobyns, 2003). Other types of malformations of cortical development (MCD), such as polymicrogyria (excessive folding and disorganization of the gyral pattern of the cortex) and focal cortical dysplasia (chaotic disorganization of the normal laminar pattern of organization), also have associated defects in the superficial cortex, suggestive of problems in the marginal zone during brain development (Eriksson et al., 2001; Garbelli et al., 2001). There have been tremendous advances in understanding the basis of normal and abnormal cortical development by studying genetic causes of MCD (Olson and Walsh, 2002). However, the most common cases of MCD presenting in humans, especially focal cortical dysplasia (usually in young adults presenting to epilepsy centers), are sporadic and thought to be attributable to an interplay of environmental and genetic factors (Montenegro et al., 2002; Sisodiya, 2004). Although it is now clear that the marginal zone and Cajal- 

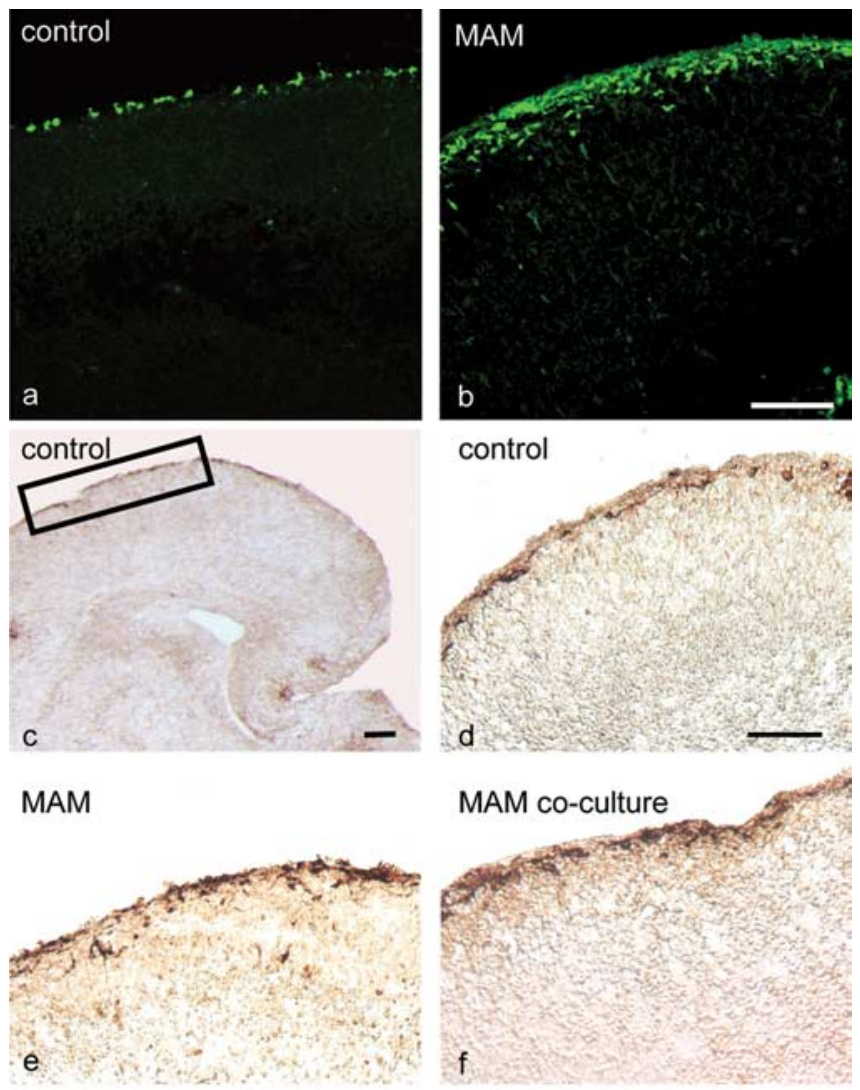

MAM co-culture +AMD3100
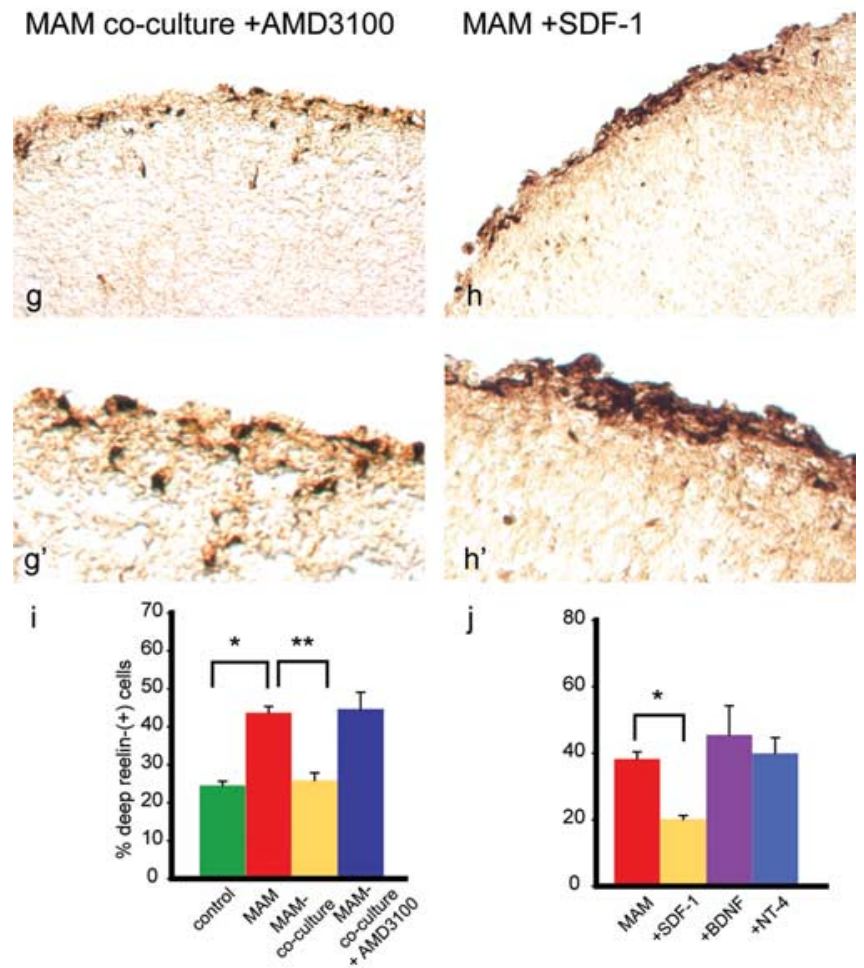

Figure 1. SDF1 is necessary and sufficient to rescue Cajal-Retzius cell positioning defects after MAM exposure. $\boldsymbol{a}, \boldsymbol{b}$, Antibody staining for Reelin shows that Cajal-Retzius cells are adjacent to the meninges in the E19 control $(\boldsymbol{a})$ but are displaced to deeper cortical layers in the same-age MAM brains ( $\boldsymbol{b}$; after MAM exposure at E15). The marginal zone in MAM-treated brains is several cell layers thick, and many reelin-positive cells appear to have no contact with either the meninges or neighboring Cajal-Retzius cells. c, Low-power view of an E20 cortical slice from a control brain cultured for 2 DIV, resectioned, and stained for reelin. The boxed area shows the region used to quantify the percentage of displaced reelin-positive cells and the approximate area shown in other panels at higher magnification. $\boldsymbol{d}$, Cortical slices (2 DIV) from
Retzius cells are key players in cortical development, there is little understanding of why it becomes so disorganized in a variety of MCD. Here we establish that defective chemokine stromalderived factor-1 (SDF1) (CXCL12) signaling causes marginal zone disorganization in a widely used teratogenic animal model of MCD in rodents. Furthermore, we establish that SDF1 signaling is required for the maintenance of Cajal-Retzius cell position during normal cortical development.

\section{Materials and Methods}

Methylazoxymethanol exposure. Pregnant Sprague Dawley (SD) rats were given injections of $25 \mathrm{mg} / \mathrm{kg}$ methylazoxymethanol (MAM; Midwest Research Institute, Kansas City, MO). Intraperitoneal injections $(0.3 \mathrm{ml}$ in dimethylsulfoxide) were made on day 15 of gestation (E15). All procedures using animals were in accordance with ethical guidelines set forth in the National Institutes of Health (NIH) Guide for the Care and Use of Laboratory Animals and were approved by the University of California, San Francisco Committee on Animal Research. Studies were designed to minimize both animal suffering and the overall number of animals used for experimentation. Animals were perfused at E16 and E19 with 4\% paraformaldehyde (PFA) in PBS. Brains were removed, fixed overnight in $4 \%$ PFA, cryoprotected in 30\% sucrose, and frozen in Optimal Cutting Temperature Compound (Tissue-Tek; Sakura Finetek, Torrance, CA). The litter size for rats treated with MAM varied between 8 and 12 pups.

Immunohistochemistry and LacZ histochemistry. Cryosectioned brain slices $(14 \mu \mathrm{m})$ were stained with antibodies against the following: laminin (rabbit; Sigma, St. Louis, MO), TuJ1 (mouse; Covance, Princeton, $\mathrm{NJ}$ ), chondroiton sulfate proteoglycan (CSPG) (mouse; Sigma), reelin (mouse; Chemicon, Temecula, CA), and 5-bromodeoxyuridine (rat; Abcam, Cambridge, MA). Colorimetric detection was achieved after exposure of the sections to diaminobenzidine (Sigma) or AlexaFluor secondary antibody conjugates (Invitrogen, Carlsbad, CA) for fluorescent immunohistochemistry.

In all of the immunohistochemistry studies, we used a minimum of four MAM-exposed and nonexposed brains. To ensure the reliability of the staining, we included negative controls in our immunostaining experiments in which we incubated the tissue in secondary antibody without previous exposure to a primary antibody. LacZ histochemistry was performed as described previously (Zhao et al., 2006).

Fluorescent in situ hybridization. Tissue was fixed in 4\% PFA for 30 min, treated with proteinase $\mathrm{K}(50 \mathrm{mg} / \mathrm{ml})$ for $1.5 \mathrm{~min}$, and fixed again with $4 \%$ PFA for $30 \mathrm{~min}$. Acetylation was performed using $0.25 \%$ acetic anhydride in $0.1 \mathrm{M}$ triethanolamine, $\mathrm{pH} 8.0$, for $10 \mathrm{~min}$, followed by three PBS washes. Slides were incubated with hybridization buffer [ $50 \%$ formamide, $5 \times$ SSC, $0.3 \mathrm{mg} / \mathrm{ml}$ yeast tRNA, $100 \mathrm{mg} / \mathrm{ml}$ heparin, $1 \times$ Denhart's, $\quad 0.1 \% \quad$ Tween $20, \quad 0.1 \% \quad$ CHAPS (3-[(3-cholamidopropyl)dimethylammonio]-1-propanesulfonate), 5 mM EDTA] for 30 min at $65^{\circ} \mathrm{C}$, followed by overnight incubation with a digoxigeninlabeled reelin probe and a fluorescein-labeled CXCR4 or SDF1 probe. Three high-stringency washes were performed with $0.2 \times$ SSC at $65^{\circ} \mathrm{C}$.

\section{$\leftarrow$}

E20 control rats show normal Cajal-Retzius cell positioning with Reelin-positive cells positioned individually along the meninges, oriented parallel to the meninges. $\boldsymbol{e}$, Slices (2 DIV) from E20 MAM-treated brains (animals treated with MAM at E15 and cultured on E20) show marginal zone disorganization similar to that seen in vivo $(\boldsymbol{b})$, with a thicker marginal zone and many scattered, chaotically oriented reelin-positive cells. $\boldsymbol{f}$, MAM slices cocultured with control slices showed rescue of the reelin-positive cells in the marginal zone. $\boldsymbol{g}$, The addition of a CXCR4 antagonist, AMD3100, to 2 DIV cocultured slices blocked the rescue of MAM slices. $\boldsymbol{h}$, SDF1 added to the culture medium without additional factors rescued the positioning of reelinpositive cells in 2 DIV slices from E20 MAM brains. $\boldsymbol{g}^{\prime}, \boldsymbol{h}^{\prime}$, Higher-power images demonstrate the ectopic position $\left(\boldsymbol{g}^{\prime}\right)$ and rescue $\left(\boldsymbol{h}^{\prime}\right)$ of Cajal-Retzius cells. $\boldsymbol{i}$, Quantification of the percentage of reelin-positive cells displaced two or more cell diameters from the meninges confirmed the qualitative impressions in all of these conditions. $j$, Quantification of the effect that exposure to BDNF, NT-4, or SDF1 had on the percentage of displaced reelin-positive cells in MAM slices. MAM slices cultured with SDF1 had significantly fewer deep reelin-positive cells than MAM slices grown with any of the other factors. Scale bars, $100 \mu \mathrm{m} .{ }^{*} p<0.05 ;{ }^{* *} p<0.01$. Error bars, SEM. 
Slides were then washed in TN buffer $(0.1 \mathrm{M}$ Tris- $\mathrm{HCl}, 0.15 \mathrm{M} \mathrm{NaCl}, \mathrm{pH}$ 7.5), treated with $1.5 \%$ peroxide in TN buffer for $20 \mathrm{~min}$, washed again with TN buffer, and blocked for $30 \mathrm{~min}$ with $0.5 \%$ blocking reagent (PerkinElmer, Wellesley, MA) in TN buffer. Slides were then incubated with horseradish peroxidase (HRP)conjugated anti-fluorescein antibody (1:1500; Roche) diluted in blocking buffer for $2 \mathrm{~h}$, followed by signal amplification using the TSA Plus Fluorescence System (PerkinElmer). Tyramide signal amplification was followed by HRP inactivation using $0.01 \mathrm{~N} \mathrm{HCl}$ for $15 \mathrm{~min}$ at room temperature. An HRP-conjugated antidigoxigenin antibody was then applied for $2 \mathrm{~h}$, followed by signal amplification using a different fluorescent color tyramide reagent from the first amplification.

Terminal deoxynucleotidyl transferasemediated biotinylated UTP nick end labeling labeling. Cell death detection was performed on fixed, frozen sections according to the DeadEnd Colormetric TUNEL System (Promega, Madison, WI). Briefly, mounted tissue was refixed in $4 \%$ PFA for $20 \mathrm{~min}$. After several PBS washes, the samples were treated with proteinase K (20 $\mathrm{mg} / \mathrm{ml}$ ) for $40 \mathrm{~s}$ (exposure time was empirically determined). After several PBS washes, tissue was immersed in equilibration buffer before the end-labeling reaction. Tissue was incubated in the terminal deoxynucleotidyltransferase reaction mix for $60 \mathrm{~min}$ at $37^{\circ} \mathrm{C}$. The reaction was stopped by immersion in $2 \times$ SSC. After several washes, the tissue was exposed to FITCconjugated streptavidin for signal detection.

Cortical slice cultures. We dissected brains from E20 untreated and MAM-treated SD rats in cold $1 \times$ Krebs' solution and prepared 250 $\mathrm{mm}$ coronal cortical sections on a Leica (Nussloch, Germany) vibratome. Slices were grown on Nucleopore Track-Etch membrane filters (Whatman, Florham Park, NJ) in serum-free medium $(1 \times$ Neurobasal medium, B-27 supplement, $0.5 \%$ glucose, penicillin/streptomycin, 2 mu GlutaMAX-1). Slices were allowed to recover for 2-3 h before pharmacological treatments were begun. For control slices (in which there was no treatment), the medium was changed to new medium. After $2 \mathrm{~d}$ in vitro (DIV), slices were fixed in 4\% PFA, cryoprotected in $30 \%$ sucrose, and frozen. For analysis, slices were recut on a cryostat into $14-\mu \mathrm{m}$-thin sections and immunostained for reelin. For pharmacological treatments, we used $50 \mathrm{ng} / \mathrm{ml} \mathrm{BDNF}$ and $100 \mathrm{ng} / \mathrm{ml} \mathrm{SDF-1a} \mathrm{(Pepro-}$ tech, Rocky Hill, NJ). AMD3100, a selective blocker of SDF1/CXCR4 function, was obtained through the NIH AIDS Research and Reference Reagent Program, Division of AIDS, National Institute of Allergy and Infectious Diseases, NIH: bicyclam JM-2987 (hydrobromide salt of AMD3100) and was used at a final concentration of $2.5 \mathrm{mg} / \mathrm{ml}$. TN14003, an SDF1/CXCR4 antagonist, was a generous gift from Dr. Nobutaka Fujii (Kyoto University, Kyoto, Japan) and was used at a final concentration of $1 \mu \mathrm{M}$.

In utero TN14003 administration. SD pregnant rats at E20 and E21 were anesthetized with $100 \mathrm{mg} / \mathrm{kg}$ ketamine, $6 \mathrm{mg} / \mathrm{kg}$ xylazine, and 2 $\mathrm{mg} / \mathrm{kg}$ acepromazine, and their uteri were exposed through their abdominal walls. The control solution was $0.9 \%$ saline solution with $0.04 \%$ trypan blue. The TN14003 was diluted, in water and 0.04\% trypan blue, to a final concentration of $1 \mu \mathrm{M}$. For each litter, the embryos from the left horn were given injections of $1-2 \mu \mathrm{l}$ of saline solution and the embryos from the right horn were given injections of 1-2 $\mu$ l of TN14003.

Statistics. All values are expressed as means \pm SEM. For statistical analysis, the Mann-Whitney $U$ test was used to calculate significance ( $p$ values) and results were designated significant at a level of $p<0.05$.

\section{Results}

\section{Disruption of the marginal zone after MAM exposure}

We previously observed severe alterations in marginal zone architecture of rats exposed in utero to a teratogen, MAM, at E15 (Paredes et al., 2006). MAM is a DNA-alkylating agent that presumably promotes toxicity predominantly by causing the accumulation of defects during DNA replication of dividing cells (Kisby et al., 1999). However, in the case of marginal zone disruption after MAM exposure, it appears that the effect on CajalRetzius cells was via a different, noncell-autonomous mechanism because, at the time of drug exposure, Cajal-Retzius cells had long finished being produced. In fact, because MAM was administered after Cajal-Retzius cells had already occupied the marginal zone (Marin-Padilla, 1998; Meyer et al., 1998), it was apparent to us that events started by MAM exposure led to active destruction of marginal zone organization rather than simply a failure to properly form. After MAM exposure, the marginal zone was thickened and many reelin-positive Cajal-Retzius cells were redistributed to deeper cortical layers (Fig. 1a,b). Dispersed cells reached far into the cortical plate and, rather than being oriented tangentially, were randomly oriented within the neocortex (Paredes et al., 

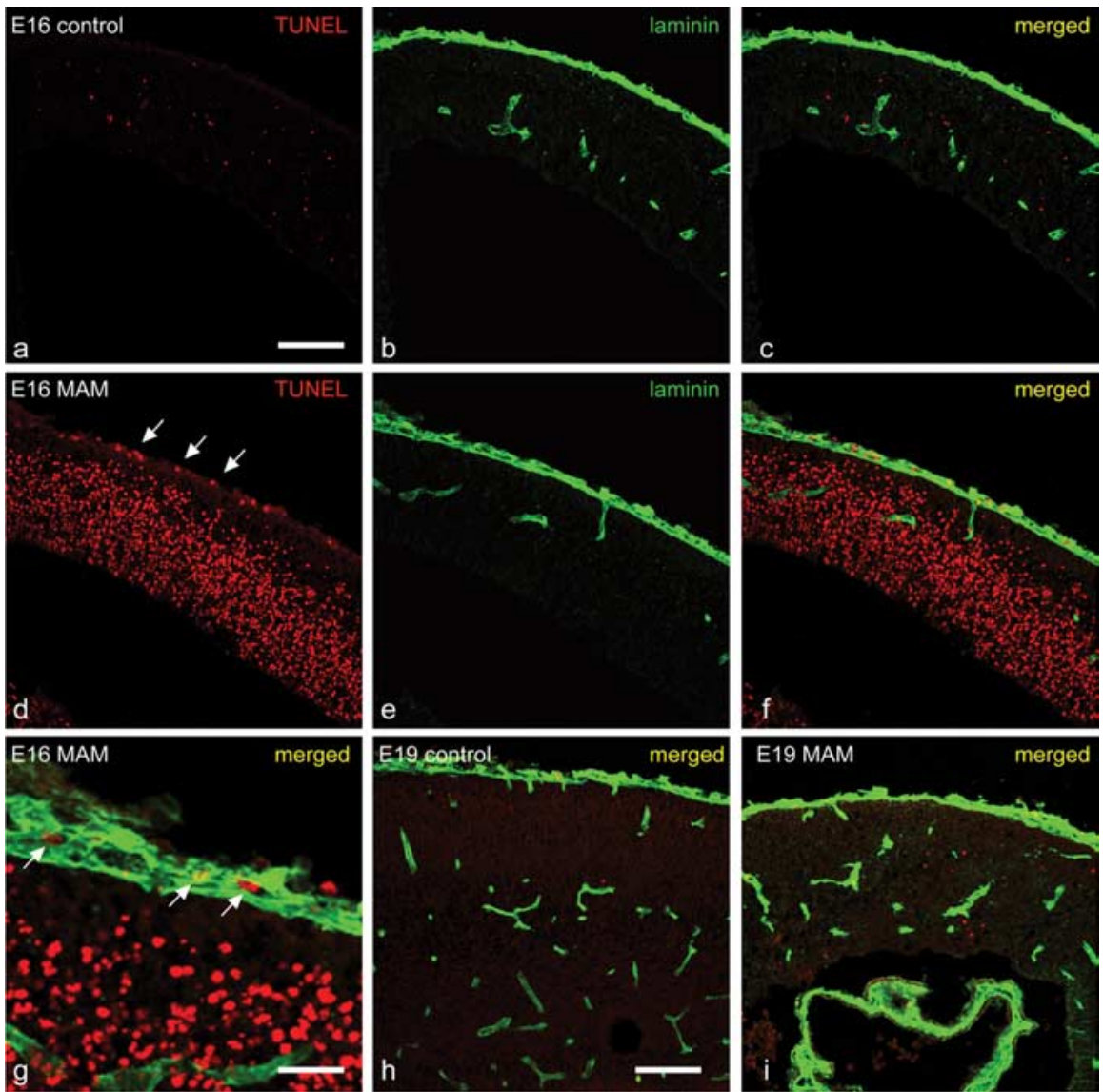

Figure 3. MAM treatment causes meningeal injury. $\boldsymbol{a}$, E16 control rat brains had a low basal level of TUNEL labeling throughout the cortical wall, indicating the commonly seen low level of developmental cell death in the developing cortex. $\boldsymbol{b}$, Laminin immunostaining marks the meningeal basement membrane and blood vessels. $c$, The merged images show minimal evidence of cell death in the meninges. $\boldsymbol{d}$, One day after MAM administration, there was evidence of dramatic increases in programmed cell death throughout the neocortex, especially in the cortical plate, the intermediate zone, and the meninges (arrows indicate TUNEL-positive cells in the meningeal layer). $\boldsymbol{e}, \boldsymbol{f}$, The overlap of TUNEL labeling and laminin staining confirms the increase in dying cells in the meninges. $\boldsymbol{g}$, Higher-magnification of the merged image from the E16 MAM-treated brain shows the numerous TUNEL-labeled cells embedded within the meningeal basement membrane (arrows indicate several apoptotic cells). $\boldsymbol{h}$, At E19, control rat neocortex had very little TUNEL labeling and retained a thick basement membrane layer. $\boldsymbol{i}$, By this time, the E19 MAM rat brain has very few TUNEL-positive cells, although still more than in control brains, and a mildly thinner meningeal basement membrane. Scale bars: $\boldsymbol{a}-\boldsymbol{f}, 130 \mu \mathrm{m} ; \boldsymbol{g}, 40 \mu \mathrm{m} ; \boldsymbol{h}, \boldsymbol{i}, 100 \mu \mathrm{m}$.

2006). Our previous studies established the identity of these cells as Cajal-Retzius cells using multiple markers (Paredes et al., 2006). Although it appears as if there may be an increased number of Cajal-Retzius cells in the cortex after MAM exposure, we demonstrated previously that this is a result of the overall smaller cortical surface area of the cortex that leads to less "stretching" of the marginal zone to cover the cortex (Paredes et al., 2006). Interestingly, there were compelling similarities between our observed disruption of the marginal zone after MAM exposure with reelin expression in surgical resections for treatment of epilepsy in patients with focal cortical dysplasia (Sisodiya, 2004).

\section{A secreted factor reverses marginal zone dysplasia}

Similar marginal zone disorganization after MAM exposure was observed previously in cortical slice cultures from MAM-exposed ferret kits, and the authors showed that a secreted factor released from control slices was able to rescue the radial glial scaffolding and Cajal-Retzius positioning defects (Hasling et al., 2003). Interestingly, a recent study showed that treatment of MAMexposed slices with neuregulin was sufficient to rescue radial glial defects but not Cajal-Retzius cell positioning defects (Gierdalski et al., 2005). This suggested that marginal zone defects after MAM exposure are reversible and that a teratogenic insult might cause marginal zone dysplasia by affecting only a small number of molecular pathways. To study this question, we prepared cortical slice cultures from E20 control rat brains and grew them for 2 DIV and found that the majority of reelin-positive cells were located in the marginal zone adjacent to the leptomeninges (Fig. 1c,d). Brain slices from age-matched MAM-exposed rats demonstrated the dispersal of reelinpositive cells away from the neocortical surface and a loss of orientation (Fig. 1e). We quantified the positioning defect by examining the percentage of strongly reelin-positive cells confined to the marginal zone versus those dispersed into deeper layers $(>2$ cell widths from the pial surface of the cortical slice). Control slices had significantly fewer reelin-positive cells in deeper layers than MAM-exposed slices (control, $24.5 \pm 1.1 \%$; MAM, $43.7 \pm$ $1.7 \% ; p<0.01 ; n=5$ slices per condition) (Fig. 1i). To determine whether secreted factors from normal slices could rescue this defect, we cultured age-matched slices from control and MAM-exposed animals together in shared medium. The marginal zone of cocultured control slices was similar to that of slices grown on their own, whereas the marginal zone of cocultured MAM slices revealed reversal of the CajalRetzius cell dispersion phenotype (Fig. 1f). Quantification of these changes (Fig. 1i) showed that the percentage of dispersed or "deep" reelin-positive cells in the marginal zone from MAM slices grown alone was statistically greater than that in the marginal zone of MAM slices cocultured with control slices $(43.7 \%$ in slices grown alone vs $25.8 \%$ in cocultured MAM-exposed slices; $p<0.01 ; n=5$ slices per condition). Thus, cocultured with control slices rescues the marginal zone disruption caused by MAM exposure. We also observed rescue of the marginal zone when we added conditioned medium (medium incubated with control slices) to cultured MAM-exposed slices (MAM, 46.2 $\pm 5.8 \%$; MAM exposed in conditioned medium, $19 \pm 3.1 \%$; $p<0.05 ; n=4$ slices per group) (Fig. 1i). It is important to note that this is a true rescue rather than a failure of the marginal zone defect to occur, because our previous in vivo analysis showed that by gestational age of slice preparation the marginal zone disruption was already quite advanced (Paredes et al., 2006), and the coculture apparently reversed this process.

\section{SDF1 signaling is sufficient and necessary to rescue Cajal-Retzius cell position}

We hypothesized that the MAM-exposed rat brain lacked a factor normally present in the leptomeninges that maintained CajalRetzius cell position in the marginal zone adjacent to the neocortical surface via a chemotactic mechanism. Previous studies suggested several candidate factors able to affect Cajal-Retzius cell 
positioning under some conditions (Brunstrom et al., 1997; Ringstedt et al., 1998; Stumm et al., 2003; Alcantara et al., 2005). We exposed slices from MAM-exposed brains separately to brain-derived neurotrophic factor (BDNF), neurotrophin-4 (NT-4), and SDF1 for 2 DIV and observed the subsequent positioning of reelin-positive cells in the marginal zone. Slices with 50 $\mathrm{ng} / \mathrm{ml} \mathrm{BDNF}$ or NT-4 added to the medium showed no rescue of the MAM phenotype (BDNF, $45.5 \pm 8.8 \%$ displaced cells; NT-4, $40 \pm 4.7 \%$ displaced cells; no factor, $39 \pm 2.2 \%$ ) (Fig. $1 j$ ). However, MAM-exposed slices incubated with $100 \mathrm{ng} / \mathrm{ml}$ SDF1 appeared quite similar to MAM exposed cocultured with control slices when stained for reelin (Fig. 1h). Quantification showed that SDF1 rescued the MAM marginal zone phenotype (39 \pm $2.2 \%$ for MAM slices alone vs $20.1 \pm 1.1 \%$ for SDF1-treated slices; $p=0.001 ; n=6$ slices per condition) (Fig. $1 j$ ). Thus, SDF1 was sufficient to rescue the localization of Cajal-Retzius cells with levels comparable to control slices or slices treated with conditioned medium.

To determine whether SDF1 signaling was also required to rescue Cajal-Retzius cell positioning, we examined whether interrupting SDF1 signaling would prevent rescue. SDF1 is the only known ligand for the chemokine receptor CXCR4, and several CXCR4 antagonist compounds have been devised (Donzella et al., 1998; Tamamura et al., 1998). Either AMD3100 or TN14003, two CXCR4 antagonists, added to cocultured MAM slices blocked rescue $(25.9 \%$ in cocultured MAM vs $44.6 \%$ in cocultured MAM slices with AMD3100; $p<0.01 ; n=5$ per condition) (Fig. 1i). Interestingly, there was no significant difference between the percentage of displaced cells in MAM-exposed slices grown alone and in cocultured MAM-exposed slices incubated with AMD3100 (Fig. 1i), indicating that blockade of CXCR4 was able to fully block the rescue by conditioned medium.

\section{Loss of SDF1 expression by the leptomeninges in MAM-treated rats}

Our data indicated that SDF1 was the factor rescuing the marginal zone phenotype in MAM-exposed rats, but was SDF1 signaling involved in the cause of marginal zone dysplasia? We reasoned that MAM exposure could lead to alterations of either SDF1 or CXCR4 [previously shown to be expressed in CajalRetzius cells (Stumm et al., 2003)] in the developing brain and that this might be sufficient to induce Cajal-Retzius cell displacement. Double in situ hybridization showed that in both control and MAM-exposed brains, reelin-positive cells adjacent to the meninges expressed CXCR4 (Fig. 2a-f). In addition, displaced reelin-positive cells in MAM-treated brains were also CXCR4 positive (Fig. $2 d-f$ ). Thus, MAM does not appear to cause CajalRetzius cell displacement by creating a subset of cells unable to respond to SDF1 because of the loss of CXCR4.

What about SDF1 expression? In the controls, reelinexpressing cells at the marginal zone were situated compactly against the SDF1-rich meninges, supporting a possible chemoattractive interaction between these cells and the meninges (Fig. $2 g$ ). In MAM-exposed brains, the SDF1 expression in the meninges was remarkably lower (Fig. $2 h$ ), and as noted above, associated with this decrease there was scattering of reelin-positive Cajal-Retzius cells to deeper cortical layers (Fig. $3 h$ ).

\section{MAM causes direct meningeal injury and defects in the meningeal basement membrane}

We wondered whether the loss of SDF1 expression in the meninges might be caused by direct injury to embryonic meninges because MAM is an alkylating agent with antiproliferative effects
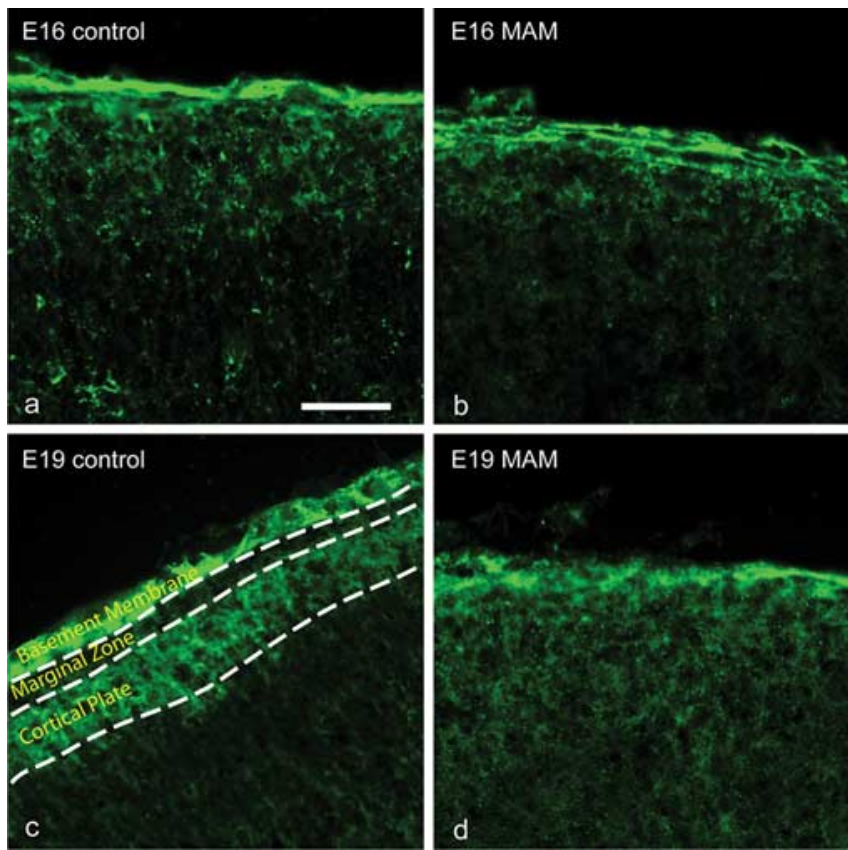

Figure 4. The meningeal basement membrane is altered after MAM exposure. $\boldsymbol{a}, \boldsymbol{b}$, CSPG expression was generally similar between the $\mathrm{E} 16$ control $(\boldsymbol{a})$ and MAM-treated $(\boldsymbol{b})$ rat brains. $\boldsymbol{c}$, $\boldsymbol{d}$, However, by $4 \mathrm{~d}$ after teratogen exposure, the meningeal basement membrane in the E19 MAM neocortex (d) was noticeably thinner than that in the control E19 neocortex (c). In addition, the normal laminar pattern of CSPG staining was abolished. Scale bar, $40 \mu \mathrm{m}$.

(Kisby et al., 1999), and the meninges undergo dramatic expansion at the same time as cortical expansion. To address this, we examined whether MAM induced apoptotic cell death in the meninges $24 \mathrm{~h}$ after injury. E16 brains from animals exposed to MAM at E15 had a remarkable and widespread increase in terminal deoxynucleotidyl transferase-mediated biotinylated UTP nick end labeling (TUNEL) labeling compared with control (Fig. $3 a-f)$. TUNEL labeling was high throughout most of the E16 neocortex: in the cortical plate, intermediate zone, ventricular zone, and meninges, but notably not in the marginal zone (Fig. $3 d-g$ ). Most of this is consistent with the widespread effects of MAM on the cortical ventricular and subventricular zones observed previously (Paredes et al., 2006); however, the presence of apoptotic cells in the meninges, but not the marginal zone, indicated that MAM exposure caused direct toxicity to the meninges rather than the Cajal-Retzius cells. Double labeling for lamininand TUNEL-positive cells confirmed that the dying cells were meningeal (Fig. $3 g$ ). Despite this increase in meningeal cell death at E16, laminin staining showed only very mild alterations in the basement membrane by E19 (Fig. 3h,i).

We examined another major constituent of the meningeal basement membrane, CSPG (McCarthy et al., 1989), and found that it was also minimally affected $1 \mathrm{~d}$ after MAM exposure (Fig. $4 a, b)$. However, by $4 \mathrm{~d}$ after exposure, the meningeal basement membrane of the MAM-exposed brain was markedly thinner, and the normal laminar organization of CSPG staining in the superficial cortex was disrupted (Fig. $4 c, d$ ). Quantification of the basement membrane thickness, as defined by CSPG staining, showed a significant difference between control brains and MAM-treated brains (control, $19 \pm 0.58 \mathrm{~mm}$; MAM, $10 \pm 1.1$ $\mathrm{mm} ; n=3$ per set; $p<0.05)$. 


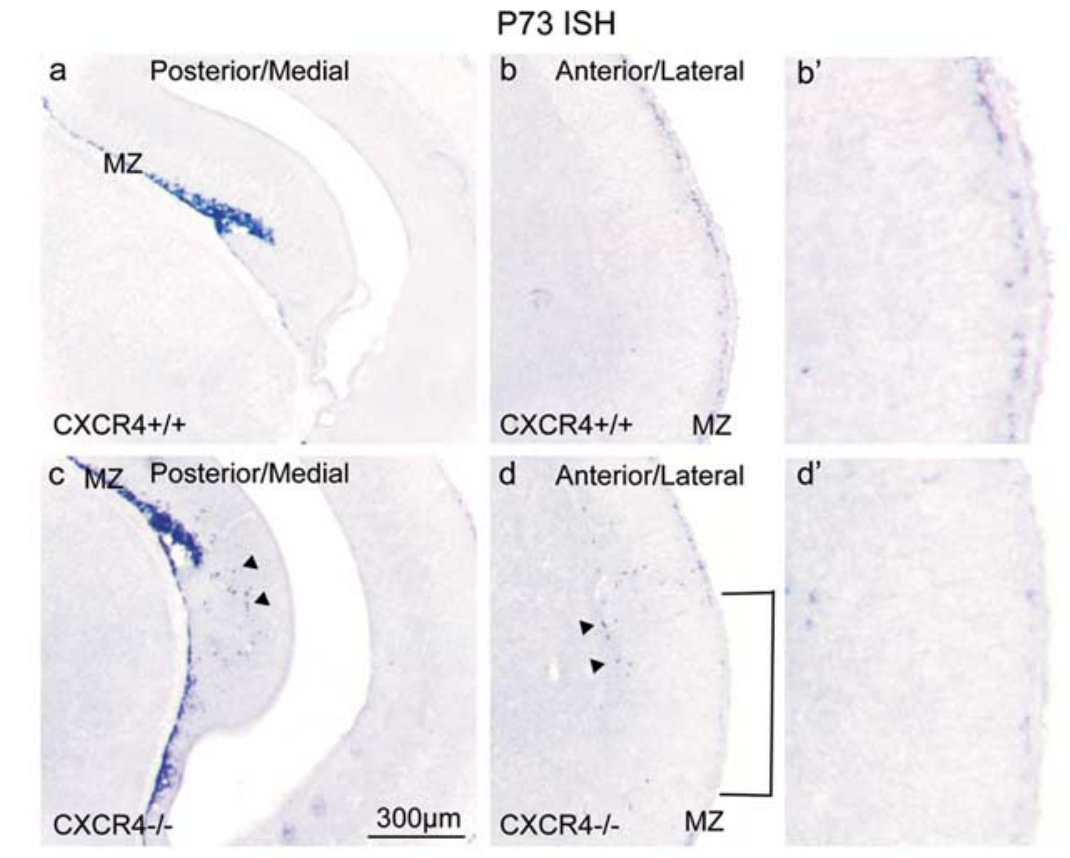

Frizzled10-LacZ

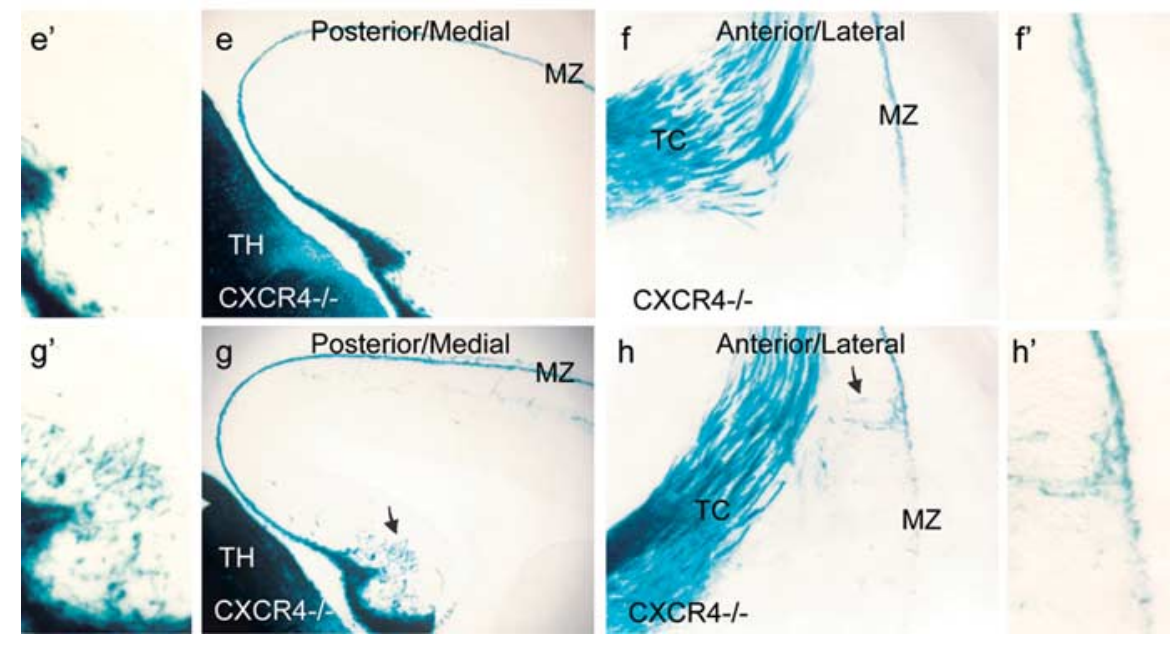

Figure 5. CXCR4 mutants have ectopic Cajal-Retzius cells. $\boldsymbol{a}-\boldsymbol{d}$, Brains from E15.5 wild-type $(\boldsymbol{a}, \boldsymbol{b})$ and CXCR4 null (c, $\boldsymbol{d})$ mice were stained by in situ hybridization (ISH) for p73, a selective marker of (ajal-Retzius cells. At posterior anatomic levels, ectopic Cajal-Retzius cells are seen in the medial cortical wall in the forming hippocampus (c, arrowheads). At more anterior levels, there are Cajal-Retzius cells displaced to deeper layers in the lateral neocortex (d, arrowheads), and there are significant gaps in the distribution of (ajal-Retzius cells in the marginal zone (see area bracketed by the lines) compared with wild type. $\boldsymbol{b}^{\prime}, \boldsymbol{d}^{\prime}$, Highpower views of the marginal zone in wild-type $\left(\boldsymbol{b}^{\prime}\right)$ and mutant $\left(\boldsymbol{d}^{\prime}\right)$ brains show the decrease in Cajal-Retzius cell density superficially in the mutant. We also crossed the Frizzled10-LacZ allele into the background of CXCR4 mutants and confirmed the findings with p73. $\boldsymbol{e}-\boldsymbol{h}$, In wild-type mice $(\boldsymbol{e}, \boldsymbol{f})$, LacZ-expressing cells are found exclusively in the marginal zone and thalamus (TH) and labeled axons in the thalamocortical projection (TC), whereas in mutants $(\boldsymbol{g}, \boldsymbol{h})$, LacZ-expressing Cajal-Retzius cells are ectopically displaced to deeper layers (arrows). $\boldsymbol{e}^{\prime}-\boldsymbol{h}^{\prime}$, High-power images show some of these findings. Scale bar: low-power images, $300 \mu \mathrm{m}$; high-power insets, $75 \mu \mathrm{m}$. MZ, Marginal zone.

\section{SDF1 signaling regulates laminar position of Cajal-Retzius cells}

Previous studies indicated that CXCR4 mutant mice had an approximate $40 \%$ reduction in the number of Cajal-Retzius cells in the marginal zone of some cortical areas, but the authors of this study believed that there were no ectopic Cajal-Retzius cells in other cortical layers (Stumm et al., 2003). Because our data suggested a possible role of meningeally expressed SDF1 as a chemoattractant for Cajal-Retzius cells, we wanted to readdress this question. Using p73 as an unambiguous marker for Cajal-Retzius cells (Meyer et al., 2004), we found the expected localization of Cajal-Retzius cells in control animals, in the marginal zone, closely abutting the meninges (Fig. $5 a, b)$. However, in mutant mice we found many Cajal-Retzius in ectopic locations of deeper cortical layers (Fig. $5 c, d$ ).

To further confirm that the mislocalized cells are Cajal-Retzius cells, we crossed Frizzled10-LacZ transgenic mice with CXCR4 mutants. We recently showed that Frizzled10-LacZ transgenic mice have abundant expression of transgene in Cajal-Retzius cells derived from the cortical hem and in the dorsal thalamus (also thalamocortical axons) (Zhao et al., 2006). In wild-type mice carrying the Frizzled10-LacZ allele, Cajal-Retzius cells are all found in the marginal zone both in medial and lateral regions of the cortex (Fig. 5e,f). In mutants, similar to our findings with p73, LacZ-expressing cells are found ectopically in deeper cortical layers, both medially and laterally, and scattered through the cortex (Fig. 5g,h).

Because the analysis of the CXCR4 mutant does not resolve whether SDF1 is involved in initial targeting of Cajal-Retzius cells to the marginal zone or in retention of these cells at superficial levels (as suggested by the MAM data), we decided to address the second possibility by incubating control slices separately with two different CXCR4 antagonists, AMD3100 and TN14003, and examining the displacement of Cajal-Retzius cells from the marginal zone. Slices with both CXCR4 blockers showed a similar magnitude of Cajal-Retzius cell position (Fig. $6 a, b$ ). The proportion of displaced reelin-positive cells in the blocker-treated slices was comparable to that in MAM slices (control: $22.1 \pm 1.7 \%$ deep cells; AMD3100 treated: $49.0 \pm 4.8 \%$ deep cells, $p<0.001$; TN14003 treated: $49.1 \pm 3.7 \%$ deep cells, $p<0.0001 ; n=7$ slices per condition) (Fig. 6b). These results are consistent with a role for SDF1 in maintaining the normal organization of the marginal zone in culture. To look for an in vivo role for SDF1 in stability of Cajal-Retzius cell position in the marginal zone, we performed in utero intraventricular injections of the CXCR4 blocker TN14300. The marginal zone of saline-injected embryos was normal up to $48 \mathrm{~h}$ after the surgery with Reelin-positive Cajal-Retzius cells found in a single-cell layer adjacent to the meninges (Fig. $6 c)(n=3)$. However, the TN14003-treated embryos showed signs of marginal zone disruption with Cajal-Retzius cell displacement from the meningeal surface as early as $24 \mathrm{~h}$ after drug injection (Fig. $6 d)(n=4$ embryos), and even more severe disruption $48 \mathrm{~h}$ after exposure to the drug (Fig. $6 e$ ) ( $n=4$ embryos). 


\section{Discussion}

SDF1 was first described as a regulator of leukocyte chemotaxis but was soon found to play several roles in brain development (Nagasawa et al., 1996; Ma et al., 1998; Zou et al., 1998; Tran and Miller, 2003). In the nervous system, SDF1 regulates the migration of sensory neuron precursor cells in dorsal root and trigeminal ganglia (Belmadani et al., 2005; Knaut et al., 2005), regulates axon guidance of spinal motor axons (Lieberam et al., 2005), and acts as a chemoattractant for embryonic cerebellar neurons (Zhu et al., 2002) and dentate granule neurons (Bagri et al., 2002). In the cerebellum, SDF1 is secreted by the meninges and is required to keep progenitor cells in the developing cerebellar cortex in the external granular layer, in proximity to the overlying meningeal cells (Reiss et al., 2002). This reveals marked similarity to the situation for Cajal-Retzius cells, except that unlike for cerebellar neurons, the role of SDF1 does not appear to be transient.

These findings shed important light on the role of the meninges in regulating cortical lamination. It is established that disruption of the meningeal basement membrane during development has important consequences for neuronal migration. In particular, genetic causes of cobblestone lissencephaly in patients and animal models of these disorders prominently include defects in meningeal basement membrane stability and glycosylation (Olson and Walsh, 2002; Kato and Dobyns, 2003). In addition, recent studies have shown that basement membrane-integrin interactions and downstream intracellular signaling components are also important regulators of superficial cortical lamination (Graus-Porta et al., 2001; Beggs et al., 2003; Niewmierzycka et al., 2005). Our findings show that the meninges are also an important source of at least one secreted ligand that regulates cortical lamination. Studies showing that focal toxic disruption of the meninges led to depletion of the marginal zone of CajalRetzius cells may have been an earlier indication of similar interactions (Super et al., 1997).

Why is maintenance of marginal zone structure by the meninges important during cortical development? One of the most dramatic aspects of cortical development prenatally is the massive expansion and increase in thickness of the cortex as gestation continues. During this process, new neuronal layers are added in an inside-out gradient with each successive layer of cells settling above the last but never migrating past the Cajal-Retzius cells. Clearly the expression and secretion of Reelin by Cajal-Retzius cells is important for this organizational principle, but it also may be important to have active mechanisms that ensure that CajalRetzius cells are always the most superficially placed neurons. Although deletion of many Cajal-Retzius cells has a deceptively subtle effect on cortical lamination (Bielle et al., 2005; Yoshida et al., 2006), in these previous models the remaining Cajal-Retzius cells from the nondeleted sources were still located in their appropriate superficial laminar location, presumably because of intact interactions with the meninges.
Previous studies have indicated that sulfated proteoglycans within the leptomeningeal basement membrane concentrate factors produced by meningeal cells, such as SDF1 (Reiss et al., 2002). There is also evidence for direct localization and presentation of SDF1 by basement membrane proteoglycans (Netelenbos et al., 2003) and that glycosaminoglycan binding regulates SDF1 dimerization (Veldkamp et al., 2005). The ability of SDF1 to bind to proteoglycans is the likely reason that conditioned media and SDF1 added to media are capable of rescuing CajalRetzius cell positioning in a localized manner. Mice or humans with mutations in genes encoding components of the meningeal basement membrane have alterations in the organization of Cajal-Retzius cells in the marginal zone (Graus-Porta et al., 2001; Halfter et al., 2002; Olson and Walsh, 2002; Beggs et al., 2003; Niewmierzycka et al., 2005). Our data suggest that when the basement membrane of the leptomeninges is disrupted, SDF1 cannot be properly concentrated at the meningeal surface, where it functions to restrict Cajal-Retzius cells to the superficial layer. It seems likely that SDF1 is not the only factor involved in regulating Cajal-Retzius cells positioning in the marginal zone because only a fraction of Cajal-Retzius cells are displaced from the marginal zone in MAM-treated animals and in slices treated with CXCR4 antagonists. It seems likely that the presence of compensating factors from early stages of development are important in allowing the fairly effective compensation in the CXCR4 mutant mice.

This study has two major findings with broad implications. First, we show that a form of marginal zone dysplasia seen in the MAM teratogenic model of MCD, which mimics key aspects of human MCD (Garbelli et al., 2001), is caused by interruption of SDF1 signaling. Even after establishment, this phenotype can be 
Control
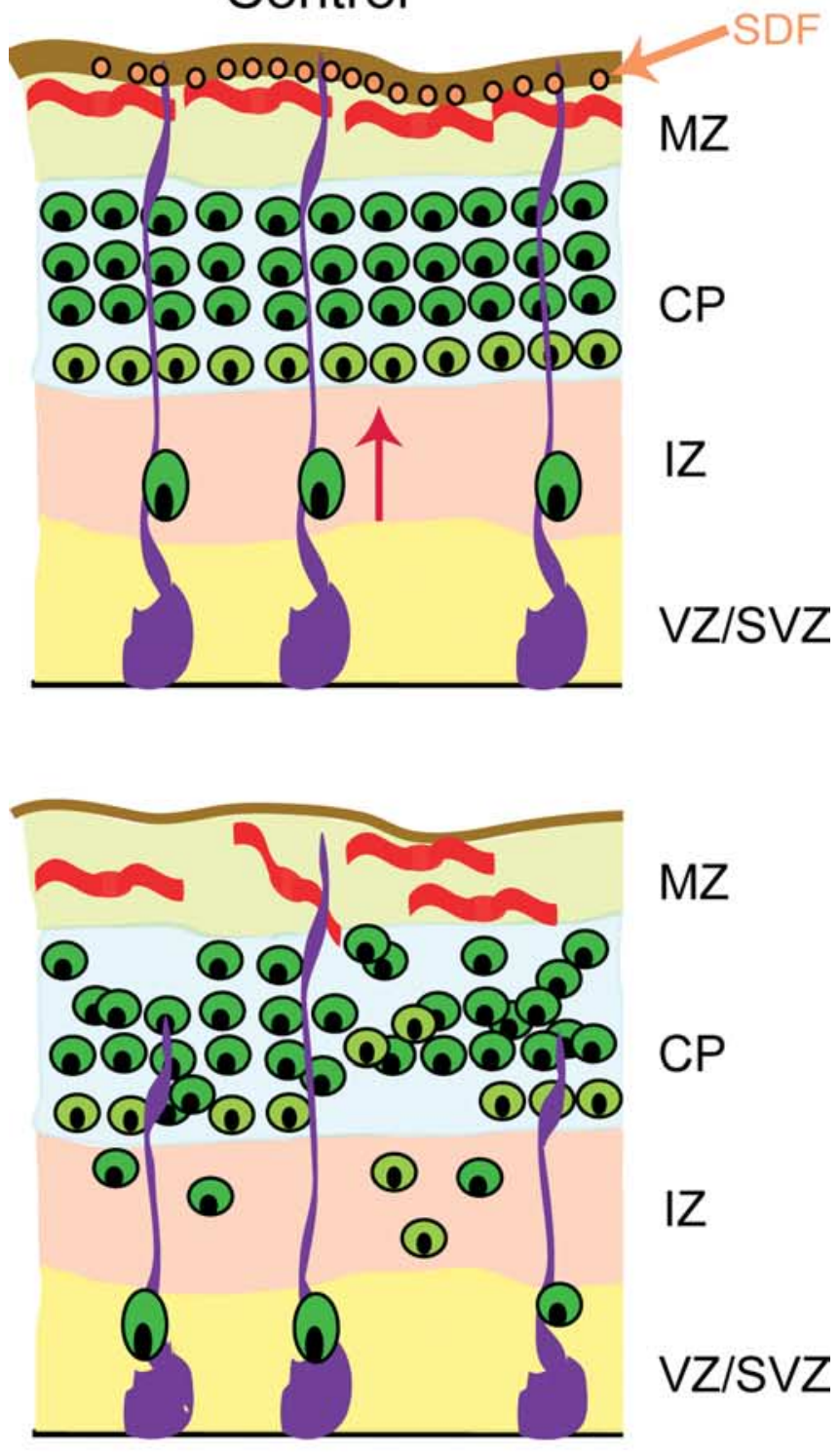

MAM

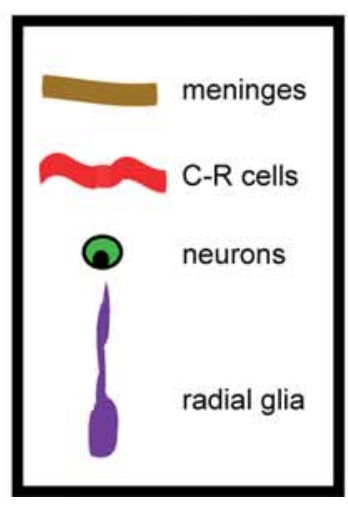

Figure 7. SDF1 signaling is required for Cajal-Retzius cell laminar position. The schematic diagram shows the normal process of lamination in the cortex and the disruption associated with delamination of Cajal-Retzius cells (C-R cells) in brains lacking normal SDF1 signaling from the meninges after MAM. MZ, Marginal zone; $C P$, cortical plate; IZ, intermediate zone; VZ/SVZ, ventricular zone/subventricular zone. rescued, a finding that could someday have therapeutic potential. Second, we show that SDF1 is required during normal corticogenesis to maintain Cajal-Retzius cell position in the marginal zone. This plastic nature of cellular position in the marginal zone indicates potentially important lessons for understanding cortical development in general. It is generally assumed that neuronal laminar positioning is a stable event once established, but our study indicates that continued signaling may be required. Because, Cajal-Retzius cells are central regulators of radial migration in the cortex, it is also possible that their displacement may have secondary effects on neocortical neuronal positioning in other layers (Fig. 7). Interestingly, a recent study showed that continued laminar integrity of the dentate granule cell layer is also dependent on continued production and signaling via a developmental regulatory molecule, in this case Reelin (Heinrich et al., 2006). Thus, there are now two examples showing that continued activity of a developmentally important modulator is required to maintain laminar integrity.

Interestingly, recent studies using genetic methods to ablate most Cajal-Retzius cells showed that the cortical lamination defects in these mice were mild compared with the defects seen in reelin mutant mice (Bielle et al., 2005; Yoshida et al., 2006). Because these studies only ablated either the medial or the lateral sources of Cajal-Retzius cells, this suggests that only a small amount of reelin may be required during cortical development to properly coordinate radial migration. However, it still seems quite likely that ectopic displacement of Reelin-expressing cells (such as in our case) may have substantial secondary effects on cortical lamination; in fact, this factor may contribute substantially to the dyslamination seen in the MAM-treated animals (Paredes et al., 2006).

Thus, we conclude that marginal zone architecture is dependent on continuous signaling by SDF1 and the integrity of the meningeal basement membrane, and that the marginal zone is a dynamic structure requiring maintenance throughout neocortical development. The conservation of marginal zone structure is likely to be critical as the cortex expands during embryogenesis so that cortical lamination can proceed unimpeded.

\section{References}

Alcantara S, Pozas E, Ibanez CF, Soriano E (2005) BDNF-modulated spatial organization of Cajal-Retzius and GABAergic neurons in the marginal zone plays a role in the development of cortical organization. Cereb Cortex 16:487-499.

Anton ES, Marchionni MA, Lee KF, Rakic P (1997) Role of GGF/neuregulin signaling in interactions between migrating neurons and radial glia in the developing cerebral cortex. Development 124:3501-3510.

Bagri A, Gurney T, He X, Zou YR, Littman DR, Tessier-Lavigne M, Pleasure SJ (2002) The chemokine SDF1 regulates migration of dentate granule cells. Development 129:4249-4260.

Beggs HE, Schahin-Reed D, Zang K, Goebbels S, Nave KA, Gorski J, Jones KR, Sretavan D, Reichardt LF (2003) FAK deficiency in cells contributing to the basal lamina results in cortical abnormalities resembling congenital muscular dystrophies. Neuron 40:501-514.

Belmadani A, Tran PB, Ren D, Assimacopoulos S, Grove EA, Miller RJ (2005) The chemokine stromal cell-derived factor-1 regulates the migration of sensory neuron progenitors. J Neurosci 25:3995-4003.

Bielle F, Griveau A, Narboux-Neme N, Vigneau S, Sigrist M, Arber S, Wassef M, Pierani A (2005) Multiple origins of Cajal-Retzius cells at the borders of the developing pallium. Nat Neurosci 8:1002-1012.

Brunstrom JE, Gray-Swain MR, Osborne PA, Pearlman AL (1997) Neuronal heterotopias in the developing cerebral cortex produced by neurotrophin-4. Neuron 18:505-517.

Donzella GA, Schols D, Lin SW, Este JA, Nagashima KA, Maddon PJ, Allaway GP, Sakmar TP, Henson G, De Clercq E, Moore JP (1998) AMD3100, a small molecule inhibitor of HIV-1 entry via the CXCR4 co-receptor. Nat Med 4:72-77. 
Eriksson SH, Thom M, Heffernan J, Lin WR, Harding BN, Squier MV, Sisodiya SM (2001) Persistent reelin-expressing Cajal-Retzius cells in polymicrogyria. Brain 124:1350-1361.

Garbelli R, Frassoni C, Ferrario A, Tassi L, Bramerio M, Spreafico R (2001) Cajal-Retzius cell density as marker of type of focal cortical dysplasia. NeuroReport 12:2767-2771.

Gierdalski M, Sardi SP, Corfas G, Juliano SL (2005) Endogenous neuregulin restores radial glia in a (ferret) model of cortical dysplasia. J Neurosci 25:8498-8504.

Graus-Porta D, Blaess S, Senften M, Littlewood-Evans A, Damsky C, Huang Z, Orban P, Klein R, Schittny JC, Muller U (2001) Betal-class integrins regulate the development of laminae and folia in the cerebral and cerebellar cortex. Neuron 31:367-379.

Halfter W, Dong S, Yip YP, Willem M, Mayer U (2002) A critical function of the pial basement membrane in cortical histogenesis. J Neurosci 22:6029-6040.

Hasling TA, Gierdalski M, Jablonska B, Juliano SL (2003) A radialization factor in normal cortical plate restores disorganized radial glia and disrupted migration in a model of cortical dysplasia. Eur J Neurosci 17:467-480.

Heinrich C, Nitta N, Flubacher A, Muller M, Fahrner A, Kirsch M, Freiman T, Suzuki F, Depaulis A, Frotscher M, Haas CA (2006) Reelin deficiency and displacement of mature neurons, but not neurogenesis, underlie the formation of granule cell dispersion in the epileptic hippocampus. J Neurosci 26:4701-4713.

Kato M, Dobyns WB (2003) Lissencephaly and the molecular basis of neuronal migration. Hum Mol Genet 12:R89-R96.

Kisby GE, Kabel H, Hugon J, Spencer P (1999) Damage and repair of nerve cell DNA in toxic stress. Drug Metab Rev 31:589-618.

Knaut H, Blader P, Strahle U, Schier AF (2005) Assembly of trigeminal sensory ganglia by chemokine signaling. Neuron 47:653-666.

Lieberam I, Agalliu D, Nagasawa T, Ericson J, Jessell TM (2005) A Cxcl12CXCR4 chemokine signaling pathway defines the initial trajectory of mammalian motor axons. Neuron 47:667-679.

Ma Q, Jones D, Borghesani PR, Segal RA, Nagasawa T, Kishimoto T, Bronson RT, Springer TA (1998) Impaired B-lymphopoiesis, myelopoiesis, and derailed cerebellar neuron migration in CXCR4- and SDF-1-deficient mice. Proc Natl Acad Sci USA 95:9448-9453.

Marin-Padilla M (1998) Cajal-Retzius cells and the development of the neocortex. Trends Neurosci 21:64-71.

McCarthy KJ, Accavitti MA, Couchman JR (1989) Immunological characterization of a basement membrane-specific chondroitin sulfate proteoglycan. J Cell Biol 109:3187-3198.

Meyer G, Soria JM, Martinez-Galan JR, Martin-Clemente B, Fairen A (1998) Different origins and developmental histories of transient neurons in the marginal zone of the fetal and neonatal rat cortex. J Comp Neurol 397:493-518.

Meyer G, Cabrera Socorro A, Perez Garcia CG, Martinez Millan L, Walker N, Caput D (2004) Developmental roles of p73 in Cajal-Retzius cells and cortical patterning. J Neurosci 24:9878-9887.

Montenegro MA, Guerreiro MM, Lopes-Cendes I, Guerreiro CA, Cendes F (2002) Interrelationship of genetics and prenatal injury in the genesis of malformations of cortical development. Arch Neurol 59:1147-1153.

Muzio L, Mallamaci A (2005) Foxg1 confines Cajal-Retzius neuronogenesis and hippocampal morphogenesis to the dorsomedial pallium. J Neurosci 25:4435-4441.

Nagasawa T, Hirota S, Tachibana K, Takakura N, Nishikawa S, Kitamura Y, Yoshida N, Kikutani H, Kishimoto T (1996) Defects of B-cell lymphopoiesis and bone-marrow myelopoiesis in mice lacking the $\mathrm{CXC}$ chemokine PBSF/SDF-1. Nature 382:635-638.

Netelenbos T, van den Born J, Kessler FL, Zweegman S, Merle PA, van Oost- veen JW, Zwaginga JJ, Huijgens PC, Drager AM (2003) Proteoglycans on bone marrow endothelial cells bind and present SDF-1 towards hematopoietic progenitor cells. Leukemia 17:175-184.

Niewmierzycka A, Mills J, St-Arnaud R, Dedhar S, Reichardt LF (2005) Integrin-linked kinase deletion from mouse cortex results in cortical lamination defects resembling cobblestone lissencephaly. J Neurosci 25:7022-7031.

Ogawa M, Miyata T, Nakajima K, Yagyu K, Seike M, Ikenaka K, Yamamoto H, Mikoshiba K (1995) The reeler gene-associated antigen on CajalRetzius neurons is a crucial molecule for laminar organization of cortical neurons. Neuron 14:899-912.

Olson EC, Walsh CA (2002) Smooth, rough and upside-down neocortical development. Curr Opin Genet Dev 12:320-327.

Paredes M, Pleasure SJ, Baraban SC (2006) Embryonic and early postnatal abnormalities contributing to the development of hippocampal malformations in a rodent model of dysplasia. J Comp Neurol 495:133-148.

Reiss K, Mentlein R, Sievers J, Hartmann D (2002) Stromal cell-derived factor 1 is secreted by meningeal cells and acts as chemotactic factor on neuronal stem cells of the cerebellar external granular layer. Neuroscience 115:295-305.

Ringstedt T, Linnarsson S, Wagner J, Lendahl U, Kokaia Z, Arenas E, Ernfors $\mathrm{P}$, Ibanez CF (1998) BDNF regulates reelin expression and Cajal-Retzius cell development in the cerebral cortex. Neuron 21:305-315.

Sisodiya SM (2004) Malformations of cortical development: burdens and insights from important causes of human epilepsy. Lancet Neurol 3:29-38.

Stumm RK, Zhou C, Ara T, Lazarini F, Dubois-Dalcq M, Nagasawa T, Hollt V, Schulz S (2003) CXCR4 regulates interneuron migration in the developing neocortex. J Neurosci 23:5123-5130.

Super H, Martinez A, Soriano E (1997) Degeneration of Cajal-Retzius cells in the developing cerebral cortex of the mouse after ablation of meningeal cells by 6-hydroxydopamine. Brain Res Dev Brain Res 98:15-20.

Super H, Del Rio JA, Martinez A, Perez-Sust P, Soriano E (2000) Disruption of neuronal migration and radial glia in the developing cerebral cortex following ablation of Cajal-Retzius cells. Cereb Cortex 10:602-613.

Takiguchi-Hayashi K, Sekiguchi M, Ashigaki S, Takamatsu M, Hasegawa H, Suzuki-Migishima R, Yokoyama M, Nakanishi S, Tanabe Y (2004) Generation of reelin-positive marginal zone cells from the caudomedial wall of telencephalic vesicles. J Neurosci 24:2286-2295.

Tamamura H, Xu Y, Hattori T, Zhang X, Arakaki R, Kanbara K, Omagari A, Otaka A, Ibuka T, Yamamoto N, Nakashima H, Fujii N (1998) A lowmolecular-weight inhibitor against the chemokine receptor CXCR4: a strong anti-HIV peptide T140. Biochem Biophys Res Commun 253:877-882.

Tran PB, Miller RJ (2003) Chemokine receptors: signposts to brain development and disease. Nat Rev Neurosci 4:444-455.

Veldkamp CT, Peterson FC, Pelzek AJ, Volkman BF (2005) The monomerdimer equilibrium of stromal cell-derived factor-1 (CXCL 12) is altered by $\mathrm{pH}$, phosphate, sulfate, and heparin. Protein Sci 14:1071-1081.

Yoshida M, Assimacopoulos S, Jones KR, Grove EA (2006) Massive loss of Cajal-Retzius cells does not disrupt neocortical layer order. Development 133:537-545.

Zhao C, Guan W, Pleasure SJ (2006) A transgenic marker mouse line labels Cajal-Retzius cells from the cortical hem and thalamocortical axons. Brain Res 1077:48-53.

Zhu Y, Yu T, Zhang XC, Nagasawa T, Wu JY, Rao Y (2002) Role of the chemokine SDF-1 as the meningeal attractant for embryonic cerebellar neurons. Nat Neurosci 5:719-720.

Zou YR, Kottmann AH, Kuroda M, Taniuchi I, Littman DR (1998) Function of the chemokine receptor CXCR4 in haematopoiesis and in cerebellar development. Nature 393:595-599. 